\title{
PERKAWINAN USIA DINI DI DESA KEBON AYU: SEBAB DAN SOLUSINYA
}

\author{
Wayan Cintya Ganes B. ${ }^{1 *}$, Ro'ihatul M. ${ }^{2}$, Dian F. ${ }^{3}$, Linawati ${ }^{4}$, Maulina D. B. ${ }^{5}$, Zulkarnaen ${ }^{6}$, \\ Nining ${ }^{7}$, Nonik N. D. ${ }^{8}$, Muh. Wahyuddin ${ }^{9}$, Abdul H. R ${ }^{10}$, I Ketut Budastra ${ }^{11}$ \\ ${ }^{1}$ Fakultas Kedokteran, Universitas Mataram, Mataram. \\ 2)3(4)577)10)Fakultas Keguruan dan IImu Pendidikan, Universitas Mataram \\ ${ }^{6}$ Fakultas Ekonomi dan Bisnis, Universitas Mataram \\ ${ }^{8}$ Fakultas Pertanian, Universitas Mataram \\ ${ }^{9}$ Fakultas Kehutanan, Universitas Mataram \\ 1)Fakultas Pertanian, Universitas Mataram \\ *Co-Author : cintyaganes@gmail.com
}

\begin{abstract}
ABSTRAK. Pendewasaan Usia Perkawinan (PUP) merupakan upaya untuk meningkatkan usia pernikahan, sehingga mencapai usia ideal pada saat melakukan pernikahan. Dengan PUP tidak sekedar menunda usia pernikahan namun juga mengusahakan agar pernikahan dilakukan pada pasangan yang dewasa dari segi ekonomi, kesehatan, kesiapan mental serta psikologi. Pernikahan usia dini, merupakan salah satu permasalahan utama yang marak terjadi di Desa Kebon Ayu. Data jumlah perkawinan di Desa Kebon Ayu (2019) menunjukkan persentase perkawinan umur perempuan dibawah 21 tahun dan laki-laki dibawah 25 tahun sebesar 80,19\%. Penyebab utama terjadinya pernikahan usia dini di Desa Kebon Ayu pada sebagian besar masyarakat yakni kesalahan penggunaan media sosial, rendahnya pendidikan dan ekonomi, pengaruh keluarga serta pola pikir masyarakat. Edukasi PUP merupakan solusi yang tepat untuk mengatasi permasalahn tersebut. Metode yang digunakan dalam penulisan artikel ini adalah metode deskriptif dan teknik wawancara mendalam digunakan dalam mengumpulkan data. Berdasarkan hasil edukasi PUP yang telah dilakukan di Desa Kebon Ayu, sebagian besar atau sekitar $97 \%$ dari 50 orang peserta mentakan pengetahuan dan kesadarannya meningkat tentang pentingnya PUP sehingga diharapkam kasus perkawinan usia dini di Desa Kebon Ayu dapat menurun. Melalui kegiatan edukasi PUP ini diharapkan masyarakat khususnya remaja untuk lebih menyadari pentingnya kesiapan sebelum menikah baik dari segi mental, usia, pendidikan dan ekonomi serta dibutuhkannya peran orang tua dalam memberikan kesempatan dan mengarahkan anak dalam menggapai pendidikan setingi-tinggnya demi terwujudnya keluarga sejahtera.
\end{abstract}

Kata Kunci: Kebon Ayu, Perkawinan, BKKBN, PUP

ABSTRACT. The adulthood of Marriage (PUP) is an effort to increase the age of marriage, thus reaching an ideal age at the time of marriage. With PUP not merely delaying the age of marriage but also to make it possible for the wedding to be done on mature couples in terms of economics, health, mental preparedness and psychology. Early childhood marriage, is one of the main problems that occur in Kebon Ayu village. The amount of marital Data in Kebon Ayu Village (2019) shows the marriage percentage of women under 21 years and males under 25 years of age at $80.19 \%$. The main cause of early childhood marriage in Kebon Ayu village to most people is the mistake of social media use, low education and economics, family influence and the mindset of society. PUP Education is the perfect solution to overcome those problems. The method used in the writing of this article is a descriptive method and in-depth interview techniques are used in collecting data. Based on the educational results of the PUP that has been done in Kebon Ayu 
village, most or about $97 \%$ of the 50 participants turned the knowledge and consciousness increased about the importance of PUP so that the case of early marriage in Kebon Ayu village can be decreased. Through the education activities of PUP is expected to be a community especially teenagers to be more aware of the importance of readiness before marriage in terms of mental, age, education and economics and the necessity of the role of parents in providing opportunities and directing the child in achieving his high-rise education for the realization of a prosperous family..

Keyword: Kebon Ayu, Marriage, BKKBN, PUP

\section{PENDAHULUAN}

Berdasarkan data penduduk Desa Kebon Ayu (2013), populasi masyarakat Desa Kebon Ayu terus bertambah dengan jumlah kelahiran anak laki-laki sebesar 43 orang dan kelahiran anak perempuan sebesar 56 orang. Hal ini yang menjadikan pernikahan dini sebagai permasalahan utama yang dihadapi oleh Desa Kebon Ayu dalam mengendalikan jumlah penduduk, sumber daya manusia, serta potensi di Desa Kebon Ayu.

Usia perkawinan yang masih tergolong muda bagi kaum perempuan akan menjadi refleksi perubahan sosial ekonomi. Pergeseran ini tidak hanya berpengaruh terhadap potensi kelahiran tetapi juga terkait dengan peran dalam pembangunan bidang pendidkan dan ekonomi. Remaja masih memerlukan bekal yang cukup untuk membangun rumah tangga, baik pendewasaan fisik, mental maupun sosial ekonomi, ilmu pengetahuan umum, agama serta pengalaman hidup dalam memulai kehidupan berumah tangga. Adapun faktor-faktor yang cukup dapat berpengaruh terhadap pembentukan konsep diri pada anak yakni faktor lingkungan masyarakat dan orang tua sebab anak bercermin pada orang tuanya yang sering kali melakukan perkawinan sedari dini. Selain itu, faktor rendahnya perekonomian keluarga juga dapat mendorong orang tua untuk menikahkan anaknya di usia yang tergolong cukup muda. Oleh karena itu, dapat dilihat bahwa peran orang tua sangat berpengaruh bagi kondisi psikologis anak.

Desa Kebon Ayu memiliki prevalensi pernikahan usia dini yang tergolong cukup tinggi. Data jumlah perkawinan di Desa Kebon Ayu (2019) menunjukkan persentase perkawinan umur perempuan dibawah 21 tahun dan laki-laki dibawah 25 tahun pada tahun 2019 sebesar 80,19\%. Penyebab utama tingginya prevalensi perkawinan usia dini di Desa Kebon Ayu antara lain adalah minimnya pengetahuan dan pemahaman remaja terkait dampak perkawinan usia dini dan kesehatan reproduksi remaja, pemahaman masyarakat akan dampak yang dapat ditimbulkan dari pernikahan usia dini yakni seperti faktor kemiskinan dan pendidikan, sosial budaya serta adanya pengaruh media dan lingkungan yang akan menyebabkan terjadinya perubahan sikap dan prilaku remaja. Maraknya pernikahan usia muda di Desa Kebon Ayu mempunyai dampak tidak baik kepada para remaja yang telah melangsungkan pernikahan sekaligus pada anak-anak yang dilahirkan dan keluarga.

Berdasarkan permasalahan tersebut, kami mahasiswa KKN menyadari akan pentingnya edukasi PUP (Pendewasaan Usia Perkawinan) sebagai salah satu solusi untuk mengatasi maraknya pernikahan usia dini di Desa Kebon Ayu. Edukasi PUP merupakan upaya untuk meningkatkan usia pernikahan sehingga mencapai usia yang ideal. Dengan PUP tidak sekedar menunda usia pernikahan namun juga mengusahakan agar pernikahan dilakukan pada pasangan 
yang dewasa dari segi ekonomi, kesehatan, kesiapan mental serta psikologi. Edukasi PUP ini bertujuan untuk memberikan pengetahuan dan meningkatkan kesadaran masyarakat tentang pentingnya pendewasaan usia pernikahan.

\section{METODE}

Metode yang digunakan dalam penulisan artikel ini adalah metode deskriptif. Sasaran dalam kegiatan edukasi PUP ini adalah masyarakat setempat, khususnya remaja dan orang tua di Desa Kebon Ayu Kecamatan Gerung.

\section{Metode Pengumpulan Data}

Metode pengumpulan data kasus perkawinan usia dini di Desa Kebon Ayu dilakukan dengan metode wawancara mendalam dengan 2 orang kader organisasi masyarakat PKK dan BKKBN serta 5 orang informan dari masyarakat yang melakukan perkawinan usia dini.

\section{Metode Pelaksanaan Edukasi PUP}

Kegiatan ini dilaksanakan pada tanggal 6 Januari 2020. Bertempat di Aula Kantor Desa Kebon Ayu, Kecamatan Gerung, Kabupaten Lombok Barat. Pada program edukasi PUP membutuhkan sarana prasarana berupa Laptop, LCD Proyektor, Sound system, spanduk, meja dan kursi.

Prosedur kerja program edukasi PUP di Desa Kebon Ayu diawali dengan mencari latar belakang dari maraknya permasalahan pernikahan usia dini di Desa Kebon Ayu, kemudian berdiskusi dengan organisasi kemasyarakatan PKK untuk menentukan waktu/ tempat beserta sasaran kegiatan dilaksanakan edukasi PUP dan mengirim surat kepada pemateri dan perangkat desa, selanjutnya mempersiapkan kegiatan edukasi PUP dan diakhiri dengan melaksanakan kegiatan edukasi PUP.

Bentuk kegiatan ini yaitu: (1) Edukasi Pendewasaan Usia Perkawinan pada Remaja.; (2) Diskusi terkait hak asasi anak, batasan usia anak dan usia pernikahan, faktor penyebab pernikahan dini, Undang-undang yang mengatur tentang perkawinan, dampak pernikahan dini dan strategi pencegahan pernikahan dini.

\section{HASIL DAN PEMBAHASAN}

Program edukasi PUP ini dilakukan secara terstruktur dan melibatkan masyarakat setempat, khususnya orang tua dan remaja.

\section{Pengumpulan Data dan Wawancara}

Kegiatan program edukasi PUP diawali dengan melakukan wawancara mendalam terlebih dahulu untuk mengumpulkan data jumlah pernikahan usia dini di Desa Kebon Ayu. Data pernikahan usia dini di Desa Kebon Ayu tahun 2019 dapat dilihat pada Tabel 3.1.

\begin{tabular}{ccclcc}
\hline No. & Suami & Istri & \multicolumn{1}{c}{ Alamat } & Suami & Istri \\
\hline 1 & And & SiA & Penarukan Daye & 19 & 16 \\
\hline 2 & Mah & MuH & Proa & 18 & 17 \\
\hline 3 & MRo & SuH & Kelebut & 19 & 17 \\
\hline 4 & AAz & KaR & Gubuk Raden & 18 & 16 \\
\hline 5 & SHa & AnS & Karang Kesume & 19 & 19 \\
\hline 6 & M. TH & SrN & Bakong & 20 & 19 \\
\hline
\end{tabular}




\begin{tabular}{ccclcc}
\hline 7 & SuL & AyA & Penarukan Lauq & 18 & 17 \\
\hline 8 & SaD & SSo & Penarukan Lauq & 17 & 16 \\
\hline 9 & SaF & RiY & Penarukan Daye & 19 & 18 \\
\hline 10 & MuN & ApL & Karang Kesume & 19 & 19 \\
\hline 11 & ArD & MuR & Proa & 19 & 18 \\
\hline 12 & SuD & IsW & Penarukan Daye & 18 & 16 \\
\hline 13 & MuZ & AsH & Gubuk Raden & 19 & 16 \\
\hline 14 & MaY & HaS & Penarukan Lauq & 17 & 19 \\
\hline 15 & LuH & KIW & Bakong & 18 & 19 \\
\hline
\end{tabular}

\section{Kasus Perkawinan di Desa Kebon Ayu beserta Sebab-sebabnya}

Dalam mengumpulkan data, kami menggunakan metode wawancara dengan teknik sampling pada beberapa informan. Oleh karena itu, berdasarkan hasil wawancara yang kami lakukan, didapatkan hasil bahwa penyebab utama terjadinya pernikahan usia dini di Desa Kebon Ayu pada 5 orang informan masyarakat yang melakukan pernikahan usia dini yakni kesalahan penggunaan media sosial, rendahnya pendidikan dan ekonomi, pengaruh keluarga serta pola pikir masyarakat.

Keberadaan sosial media dapat memberikan banyak manfaat bagi para pengguna karena lebih mudah untuk saling berkomunikasi melalui sosial media atau lebih modernnya bersosialisasi secara digital, walaupun antara orang yang satu dan lainnya tidak saling bertatap muka secara langsung. Semakin berkembangnya sosial media semakin banyak pula penggunanya, mulai dari kalangan lansia hingga anak di bawah umur yang sebenarnya belum dapat menggunakan gadget ataupun smartphone dan mengakses internet khususnya sosial media. Namun kenyataannya sosial media tersebut keberadaanya tidak sesuai dengan kenyataan yang ada. Hal ini dikarenakan, sosial media lebih banyak mengandung konten-konten yang tidak semestinya dapat diakses oleh anak di bawah umur, contoh konkritnya konten pornografi. Akibatnya remaja akan kecanduan seks sehingga apa yang mereka lihat pada tayangan atau gambar porno tersebut dilakukan dikehidupan seharihari, hingga muncullah seks bebas dikalangan remaja itu sendiri, maka otomatis pernikahan dini karena hamil diluar nikah juga meningkat (Ibrahim dkk, 2018).

Rendahnya pendidikan dan ekonomi juga dapat menjadi pemicu terjadinya pernikahan dini. Tentunnya tingkat ekonomi keluarga juga sangat berpengaruh pada tingkat pendidikan anggota keluarga. Rendahnya pendapatan ekonomi keluarga akan menekan anak untuk putus sekolah dan tidak melanjutkan pendidikan kejenjang yang lebih tinggi lagi. Pendidikan merupakan salah satu faktor yang mempengaruhi persepsi seseorang, dengan pendidikan tinggi seseorang akan lebih mudah menerima atau memilih suatu perubahan yang lebih baik. Tingkat pendidikan menggambarkan tingkat kematangan kepribadian seseorang dalam merespon lingkungan yang dapat mempengaruhi wawasan berpikir atau merespon pengetahuan yang ada di sekitarnya.

Berdasarkan hasil penelitian diperoleh bahwa rata-rata pendidikan orang tua maupun informan itu sendiri masih tergolong rendah. Tidak ada informan yang melanjutkan pendidikannya ke perguruan tinggi. Rendahnya tingkat pendidikan disebabkan oleh ekonomi keluarga yang kurang. Kekurangan biaya dapat menjadi kendala bagi anak untuk melanjutkan pendidikan. Selain itu, ketika kemiskinan menjadi permasalahan yang mendesak, perempuan muda sering dikatakan sebagai beban ekonomi keluarga. Oleh karenanya pernikahan usia muda dianggap sebagai suatu solusi untuk mendapatkan harta dari pihak laki-laki untuk menganti seluruh biaya hidup yang telah 
dikeluarkan oleh orangtuanya. Informan mengutarakan, ia memutuskan menikah untuk meringankan beban orang tuannya. Secara sosial ekonomi, pernikahan usia muda menjadi salah satu gejala yang menunjukkan rendahnya status wanita. Pada beberapa kasus, pernikahan usia muda berkaitan dengan terputusnya kelanjutan sekolah wanita yang berakibat pada tingkat pendidikan wanita menjadi rendah. Pendidikan yang rendah akan merugikan posisi ekonomi wanita dan rendahnya tingkat partisipasi kerja wanita. Menurut Hanum (2010), faktor ekonomi yang berkaitan dengan lapangan pekerjaan dan kemiskinan penduduk memberikan andil bagi berlangsungnya pernikahan usia dini.

Faktor keluarga merupakan faktor adanya pernikahan usia muda, dimana keluarga dan orang tua akan segera menikahkan anaknya jika telah beranjak dewasa. Hal ini tergolong sudah biasa atau bersifat turun-temurun. Sebuah keluarga yang mempunyai anak gadis tidak akan merasa tenang sebelum anak gadisnya menikah. Orang tua akan merasa takut apabila anaknya akan melakukan hal-hal yang tidak diinginkan yang akan mencemari nama baik keluarganya. Hal inilah yang dialami oleh salah satu informan. la menikah karena orang tuannya takut jika anaknya melakukan hubungan yang tidak diinginkan dengan pacarnya.

\section{Dampak Perkawinan Usia Dini}

Dewasa ini, menurut Fadjar (2018), adapun dampak pernikahan dini dari berbagai aspek yang mencakup hukum, biologis, psikologis, pendidikan dan administrasi kependudukan.

\section{Dampak Hukum}

Adanya pelanggaran terhadap Undang-Undang yang telah ditetapkan yakni, UU No. 1 Tahun 1974 tentang Perkawinan, pada pasal 7 (1), perkawinan hanya diizinkan jika pihak pria telah mencapai usia 19 tahun dan pihak wanita telah mencapai usia 16 tahun. Pasal 6 ayat (2), untuk melangsungkan perkawinan seseorang yang belum mencapai usia 21 tahun harus mendapatkan izin kedua orang tua. UU No. 23 tahun 2002 tentang Perlindungan Anak, pasal 26 (1) menyatakan bahwa orang tua berkewajiban dan bertanggungjawab untuk: mengasuh, memelihara, mendidik dan melindungi anak, menumbuhkembangkan anak sesuai dengan kemampuan, bakat dan minatnya serta mencegah terjadinya perkawinan pada usia anak-anak. Amanat UU tersebut bertujuan untuk melindungi anak agar tetap memproleh haknya untuk hidup, tumbuh dan berkembang serta melindunginya dari perbuatan kekerasan, eksploitasi dan diskriminasi.

\section{Dampak Biologis}

Secara biologis, organ reproduksi anak masih dalam proses menuju kematangan, sehingga belum siap untuk melakukan fungsinya. Kematangan fisik seorang anak, tidak sama dengan kematangan psikologisnya sehingga meskipun anak tersebut memiliki badan gemuk dan telah menstruasi tetapi secara perilaku tetap tergolong anak-anak.

\section{Dampak Psikologis}

Secara psikis anak juga belum siap dan mengerti tentang hubungan seks, sehingga akan menimbulkan trauma psikis berkepanjangan. Kematangan psikologis ibu menjadi hal utama, karena sangat berpengaruh terhadap pola asuh anak dikemudian hari. 


\section{Dampak Pendidikan}

Pernikahan dini mengakibatkan anak tidak mampu mencapai pendidikan yang lebih tinggi. Pendidikan yang rendah akan mengakibatkan sulitnya memperoleh penghasilan yang layak. Sehingga keluarga akan menjadi beban perekonomian yang cukup berat.

\section{Dampak Administrasi Kependudukan}

Dampak administrasi kependudukan dapat berupa, tidak memiliki akte nikah dan tidak memiliki kartu keluarga. Apabila dikemudian hari terjadi perceraian, akan sulit untuk mengurus pembagian warisan.

\section{Solusi Potensial untuk Menekan Jumlah Kasus Perkawinan Usia Dini di Desa Kebon Ayu}

Dalam mencegah dan mengurangi prevalensi pernikahan dini di Desa Kebon Ayu, upaya yang dapat dilakukan salah satunya melalui kegiatan edukasi PUP yang diselanggarakan oleh mahasiswa KKN Tematik Universitas Mataram beraliansi dengan organisasi kemasyarakatan PKK dan BKKBN Provinsi NTB.

Kegiatan program edukasi PUP dilaksanakan pada hari Senin, 6 Januari 2020 pukul 09.00 bertempat di Aula Kantor Desa Kebon Ayu dengan sasaran kegiatan masyarakat setempat khususnya remaja dan orang tua. Kegiatan edukasi PUP di Desa Kebon Ayu dapat dilihat pada Gambar 31.

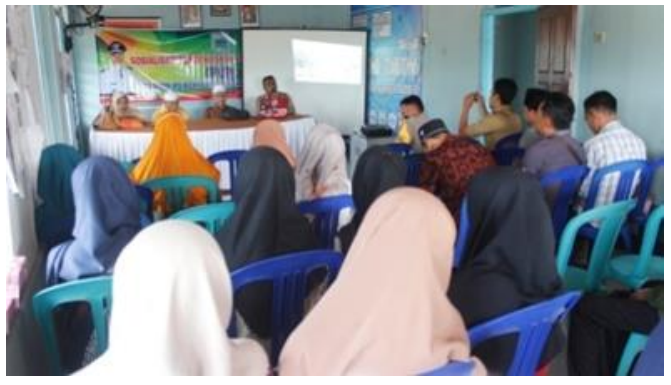

Gambar 1. Kegiatan Edukasi PUP

Pendewasaan Usia Perkawinan (PUP) merupakan upaya untuk meningkatkan usia pada pernikahan, sehingga mencapai usia ideal untuk melakukan pernikahan. PUP bukan sekedar menunda sampai usia tertentu saja tetapi mengusahakan agar pernikahan dilakukan pada pasangan yang telah dewasa dari segi ekonomi, kesehatan, mental maupun psikologi. Adapun tujuan program pendewasaan usia pernikahan adalah memberikan pengertian dan kesadaran kepada remaja agar sewaktu merencanakan keluarga, mereka dapat mempertimbangkan berbagai aspek yang berkaitan dengan kehidupan berkeluarga, kesiapan fisik, mental, emosional, pendidikan, sosial, ekonomi serta menentukan jumlah dan jarak kelahiran.

Tujuan PUP berimplikasi pada perlunya peningkatan usia pernikahan yang lebih dewasa. Program Pendewasaan Usia Perkawinan dalam program KB bertujuan untuk meningkatkan usia pernikahan perempuan pada umur 21 tahun serta menurunkan angka kelahiran anak pada usia ibu di bawah 21 tahun. Pendewasaan Usia Perkawinan dan Perencanaan Keluarga merupakan kerangka dari program Pendewasaan Usia Perkawinan. Kerangka ini terdiri dari empat masa reproduksi sebagaimana yang disebutkan oleh Fadjar (2018), yaitu: a) Masa menunda perkawinan 
dan kehamilan, b) Masa mencegah kehamilan dan c) Masa menjarangkan kehamilan dan d) Masa mengakhiri kehamilan.

\section{Masa Menunda Perkawinan dan Kehamilan}

Menurut Hurlock (1993), laki-laki, organ pendewasaan usia perkawinan dan hak-hak reproduksi bagi remaja di usia 14 tahun hanya sekitar 10\% dari ukuran matang. Setelah dewasa, ukuran dan proporsi tubuh serta organ reproduksi akan berkembang. Pada laki-laki, kematangan organ reproduksi terjadi pada usia 20 atau 21 tahun sedangkan organ reproduksi perempuan tumbuh pesat pada usia 16 tahun. Pada waktu tahun pertama menstruasi dikenal dengan tahap kemandulan remaja dimana, tidak dapat menghasilkan ovulasi atau pematangan dan pelepasan sel telur yang telah matang dari folikel di dalam indung telur. Organ reproduksi dapat dikatakan sudah cukup matang pada usia diatas 18 tahun, pada usia ini rahim (uterus) bertambah panjang dan indung telur bertambah besar. Dalam masa reproduksi, usia di bawah 20 tahun adalah usia yang dianjurkan untuk menunda perkawinan dan kehamilan. Pada usia ini seorang remaja masih dalam masa pertumbuhan baik secara fisik maupun psikis.

Proses pertumbuhan berakhir pada usia 20 tahun, maka dianjurkan perempuan menikah pada usia 20 tahun. Apabila pasangan suami istri menikah pada usia tersebut, maka dianjurkan untuk menunda kehamilan sampai usia istri 20 tahun dan dengan menggunakan alat kontrasepsi.

\section{Masa Mencegah Kehamilan}

Perempuan yang menikah pada usia dibawah 20 tahun dianjurkan untuk menunda kehamilannya hingga usianya minimal 20 tahun. Untuk menunda kehamilan pada masa ini ciri kontrasepsi yang diperlukan adalah kontrasepsi yang mempunyai reversibilitas dan efektivitas tinggi. Kontrasepsi yang dianjurkan adalah kondom, Pil, IUD, implan dan suntik.

\section{Masa Menjarangkan Kehamilan}

Masa menjarangkan kehamilan terjadi pada periode Pasangan Usia Subur (PUS) berada pada umur 20-35 tahun, merupakan periode yang paling baik untuk hamil dan melahirkan karena resiko paling rendah bagi ibu dan anak. Jarak ideal untuk menjarangkan kehamilan adalah 5 tahun, sehingga tidak ada 2 balita dalam 1 periode. Untuk menjarangkan kehamilan dianjurkan menggunakan alat kontrasepsi. Pemakaian alat kontrasepsi pada tahap ini dilaksanakan untuk menjarangkan kelahiran agar ibu dapat menyusui anaknya dengan baik dan benar. Semua kontrasepsi, yang dikenal sampai sekarang dalam program Keluarga Berencana Nasional, pada dasarnya cocok untuk menjarangkan kelahiran. Akan tetapi dianjurkan setelah kelahiran anak pertama langsung menggunakan alat kontrasepsi spiral (IUD).

\section{Masa Mengakhiri Kehamilan}

Masa mengakhiri kehamilan, berada pada usia di atas 35 tahun, sebab secara empiris diketahui ibu yang melahirkan anak di atas 35 tahun akan banyak mengalami resiko medis. Ciri kontrasepsi yang dianjurkan kini adalah kontrasepsi dengan efektivitas tinggi, dapat digunakan jangka panjang dan tidak menyebabkan kelainan (pada usia tua kelainan seperti penyakit jantung, darah tinggi, tumor atau kanker dan penyakit metabolik biasanya meningkat, oleh karena itu sebaiknya tidak diberikan kontrasepsi yang dapat menyebabkan kelainan tersebut semakin parah). Kontrasepsi yang dianjurkan adalah steril, IUD dan Implan. 
Adapun batasan usia dalam melangsungkan perkawinan merupakan bahasan yang sangat penting. Hal ini dikarenakan, di dalam suatu perkawinan dianjurkan kedewasaan secara psikologis. Usia perkawinan yang tergolong cukup muda dapat mengakibatkan peningkatan kasus perceraian dikarenakan minimnya kesadaran untuk bertanggung jawab dalam kehidupan berumah tangga bagi suami dan istri. Meskipun batas usia perkawinan telah ditetapkan dalam pasal 7 ayat (1) UU No. 1 Tahun 74, yakni perkawinan hanya diizinkan jika pihak pria telah mencapai usia 19 tahun dan pihak wanita telah mencapai umur 16 tahun. Namun kenyataannya masih banyak dijumpai perkawinan di bawah umur.

Undang-Undang Nomor 23 tahun 2002, tentang Perlindungan Anak pasal 1, menjelaskan bahwa anak merupakan seseorang yang belum berusia 18 tahun, termasuk yang masih dalam kandungan. Hak anak adalah bagian dari hak asasi manusia yang wajib dilindungi dan dipenuhi oleh orangtua, masyarakat, pemerintah dan negara.

Nusa Tenggara Barat merupakan provinsi pertama yang mengatur pendewasaan usia perkawinan, dengan terbitmya Surat Edaran Nomor 150/1138/Kum tahun 2014, tentang PUP yang merekomendasikan usia perkawinan untuk laki-laki dan perempuan minimal 21 tahun. Surat edaran ini diterbitkan untuk mendorong seluruh perangkat daerah yang mencakup bupati atau wali kota seNTB untuk melaksanakan program PUP sesuai dengan tugas dan tanggung jawab masing-masing.

Undang-Undang RI Nomor 4 tahun 1979 tentang Kesejahteraan Anak, menyebutkan bahwa anak adalah mereka yang belum berusia 21 tahun dan belum menikah. Maka, secara keseluruhan dapat dilihat bahwa rentang usia anak terletak pada skala 0 sampai dengan 21 tahun. Penjelasan mengenai batas usia 21 tahun ditetapkan berdasarkan pertimbangan kepentingan usaha kesejahteraan sosial, kematangan pribadi dan kematangan mental seseorang yang umumnya dicapai setelah seseorang melampaui usia 21 tahun.

Undang-undang ini dapat dikatakan tumpang tindih dengan undang-undang nomor 23 Tahun 2002 tentang perlindungan anak yang menyatakan bahwa usia $<18$ tahun tergolong masih anakanak. Selain itu UU No. 1 Tahun 1974 tentang perkawinan juga tidak mendukung kampanye program Generasi Berencana BKKBN dimana, usia menikah ideal untuk perempuan adalah di atas 20 tahun dan laki-laki adalah di atas 25 tahun.

Berdasarkan hasil edukasi PUP yang telah dilakukan di Desa Kebon Ayu, sebagian besar atau sekitar $97 \%$ dari 50 orang peserta mentakan pengetahuan dan kesadarannya meningkat tentang pentingnya PUP sehingga diharapkam kasus perkawinan usia dini di Desa Kebon Ayu dapat menurun. Oleh karena itu, melalui kegiatan edukasi PUP diharapkan masyarakat khususnya remaja dan orang tua lebih menyadari pentingnya kesiapan sebelum menikah baik dari segi mental, usia, pendidikan dan ekonomi demi terwujudnya keluarga sejahtera. 


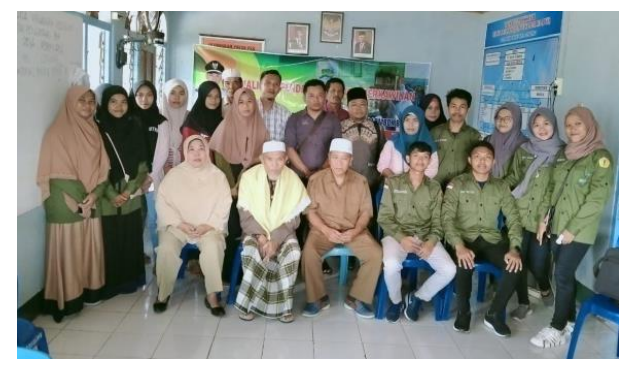

Gambar 1. Dokumentasi Kegiatan PUP

\section{KESIMPULAN}

Berdasarkan latar belakang permasalahan yang menjadi penyebab utama terjadinya pernikahan usia dini di Desa Kebon Ayu pada sebagian besar masyarakat yakni kesalahan penggunaan media sosial, rendahnya pendidikan dan ekonomi, pengaruh keluarga serta pola pikir masyarakat. Oleh karena itu melalui kegiatan KKN Tematik BKKBN mahasiswa menyelenggarakan program edukasi PUP sebagai upaya untuk meningkatkan usia pernikahan. Berdasarkan hasil edukasi PUP yang telah dilakukan di Desa Kebon Ayu, sebagian besar atau sekitar $97 \%$ dari 50 orang peserta mentakan pengetahuan dan kesadarannya meningkat tentang pentingnya PUP sehingga diharapkam kasus perkawinan usia dini di Desa Kebon Ayu dapat menurun. Oleh karena itu, melalui kegiatan edukasi PUP diharapkan masyarakat khususnya remaja dan orang tua lebih menyadari pentingnya kesiapan sebelum menikah baik dari segi mental, usia, pendidikan dan ekonomi demi terwujudnya keluarga sejahtera.

Berdasarkan kesimpulan, kami mahasiswa KKN mencoba memberikan masukan atau beberapa saran yang ditunjukkan kepada semua pihak yang mempunyai kepentingan. Adapun saran kami, bagi para orang tua alangkah baiknya jika anak diberi kesempatan untuk menggapai pendidikan setingi-tingginya dan mengarahkan anak untuk menggunakan media sosial secara bijak, sehingga dapat mencegah terjadinya pernikahan usia dini. Selain itu, bagi pasangan usia muda sebaiknya sebelum memutuskan untuk menikah harus mempertimbangkan terlebih dahulu kematangan seperti fisik dan finansial.

\section{REFERENSI}

Andika, Agus. (2019). Data Jumlah Perkawinan Desa Kebon Ayu, Kecamatan Gerung Kabupaten Lombok Barat Bulan JanuariDesember 2019. Desa Kebon Ayu: PPKBD Desa Kebon Ayu, hal:1-12.

Badan Koordinasi Keluarga Berencana Nasional (BKKBN). (2010). Pendewasaan Usia Perkawinan dan Perlindungan Hak-hak Reproduksi bagi Remaja Indonesia, Cetakan Edisi ke-2. Jakarta: Direktorat Remaja dan Hak-hak Reproduksi Remaja, hal: 96-100.

Hurlock, Elizabeth B. (1993) . Psikologi Perkembangan Anak, Jilid 2. Jakarta: Penerbit Erlangga.

Fadjar, Mulyadi. (2018). Pendewasaan Usia Perkawinan. Jurnal PUP, Vol.1 No.1, p.1-4.

Hanum. (2010). Perkawinan Usia Belia. Jurnal Penelitian, Vol.1 No.1, p.1-5.

Ibrahim, I.Z., Rahmaniar, Nur, A.Z., Mildawati dan Asdita,R.R. (2018). Penyalahgunaan Sosial Media pada Anak dibawah Umur dalam Mengakses Pornografi. JurnalPenelitian,Vol.1No.1,p.1-13. 